Çukurova Üniversitesi Mühendislik Mimarlık Fakültesi Dergisi, 29(2), 13-26 ss., Aralık 2014

Çukurova University Journal of the Faculty of Engineering and Architecture, 29(2), pp.13-26, December 2014

\title{
Mısır Koçanı Katkılı Isı Yalıtım Malzemesi Üretimi
}

\section{Hanifi BINICíi ${ }^{* 1}$, Ahmet H. SEVINÇ ${ }^{1}$, Mustafa EKEN ${ }^{1}$, Ceyda DEMIRHAN ${ }^{1}$}

\author{
${ }^{1}$ Kahramanmaraş Sütçü Imam Üniversitesi, Mühendislik Mimarlık Fakültesi,
} Inşaat Mühendisliği Bölümü, Kahramanmaraş

Geliş tarihi: 10.07.2014 Kabul tarihi: 11.12.2014

\section{Özet}

Türkiye'de kışın ısınma maliyetleri, yazın ise soğutma masrafları çok fazla olduğundan bu maliyetleri azaltmak için binalara yalıtım yapılmaktadır. Yalıtım malzemelerin ham maddelerinin çok büyük bir kısmı yurt dışından ithal edilmektedir. Türkiye'de önemli miktarda mısır üretimi gerçekleştiriliyor. Türkiye'de harcanan enerjinin yaklaşı \%40'ı konutlarda tüketilmektedir. Bu enerjinin \%80'i de 1sınma amaçlıdır. Binalar ve yerleşimler küresel ısınmaya sebep olan başlıca sera gazı olan $\mathrm{CO}_{2}$ salınımının $\% 40$ 'ından sorumludur. Bu nedenle, binaların 1sitılmasında gerekli olan enerjiyi en aza indirmek için çeşitli yalıtım sistemleri ve yalıtım malzemeleri kullanılmaktadır. Bu çalışmada, bütün durumlar göz önüne alınarak standartlara uygun öğütülmüş mısır koçanları ve bağlayıcı olarak epoksi ile 1sı yalıtım malzemesi üretilmesi amaçlanmıştır. Üretilen yalıtım malzemesinin birim hacim ağırlı̆̆ı, su emme, ses geçirimliliği ve isı iletim katsayısı bulunmuştur. Mısır koçanı esaslı yalıtım malzemesi 1sı iletim katsayısı 0,075'e kadar inmiştir. Ayrıca bağlayıcı olarak değişik oranlarda alçı ve çimento kullanılarak yalıtım malzemesi üretilmiştir. Bu örneklerde yalıtım değerleri kabul edilebilir sınırlardadır.

Anahtar Kelimeler: Isı yalıtım, Mısır koçanı, Yalıtım malzemeleri

\section{Corn on the Cob Added Heat Insulation Material Production}

\begin{abstract}
Winter heating costs in Turkey, type the cooling costs of the building insulation is to reduce these costs is too much. A very large part of the raw material of insulation material is imported from abroad. A significant amount of corn production is carried out in Turkey. Around $40 \%$ of the energy consumed in Turkey is consumed in it. $80 \%$ of this energy is for heating. And residential buildings are responsible for $40 \%$ of $\mathrm{CO}_{2}$ emissions, the main geenhouse gas responsible for global warming. Therefore, the energy required for heating premises various insulation systems and heat insulation materials are used to minimize. This study aims, considering all circumstances according to standard epoxy gound corn cobs, and the binder is made of heat insulation material. Unit weight of the produced insulating materials, water absorption, the sound permeability and the heat transfer coefficient was found. Corncob-based insulation material heat transmission coefficient was down to 0,075. Further the binder is made of insulating material using as gypsum and cement at different rates. These examples are in acceptable limits insulation values.
\end{abstract}

Keywords: Thermal insulation, Corn on the cob, Insulation materials

\footnotetext{
*Yazışmaların yapılacağı yazar: Hanifi BİNİĊ, Kahramanmaraş Sütçü İmam Üniversitesi, Mühendislik Mimarlık Fakültesi, İnşaat Müh. Bölümü, Kahramanmaraş, hbinici@ksu.edu.tr
} 


\section{GİRIŞ̧}

İlk insanların doğanın olumsuz etkilerinden korumak için avladıkları hayvanların postlarına sarınması ilk 1sı yalıtımının başlangıcı kabul edilebilir. Ancak, gerçek anlamda 1sı yalıtımı, 19. yüzyılda sanayi devrimi ile buharla çalışan kazanlarda yüksek verim elde etmek için yalıtım ihtiyacı ortaya çıkmıştır. 1882 yılında Cari VonLinde'nin ilk soğutma makinesini bulması ile soğuk hava deposu yapılmıştır. Bu depoda uzun süre soğuk havadan yararlanmak için 1sı yalıtım malzemelerine ihtiyaç olduğu, geleneksel inşaat malzemeleri ile bu görevin yerine getirilemeyeceği ortaya çıkmıştır. Bu malzemelere genel olarak, "Yalıtım Malzemesi" denilmiş, ancak zamanla her yalıtım malzemesinin hem soğuk hava depoları için hem de buhar kazanlarında kullanılamayacağ ortaya çıkmıştır. 1900 yılların başlarında Almanya'da isı yalıtım malzemelerinin seri üretimine başlanmıştır [1].

20. yüzyılın başından itibaren yapılarda yalıtım malzemeleri yaygın olarak kullanılmaktadır. Yeni yapı ve yapım sistemlerinin, sağladıkları birçok yararın yanı sıra, yapı fiziği ve konfor şartları açısından bazı sakıncalarının da olduğu zamanla ortaya çıkmıştır. Dış duvarların taşıyıcı sisteme yük getirmemesi ve ince olarak tasarlaması kabul görmüştür. Fakat bu durum diş etkenlerden etkilenmeden uzun süre işlevi koruması için, farklı malzemelerden ve katmanlardan oluşacak şekilde tasarlanması gereği ortaya çıkmıştır. Çok katmanlı duvarlarda kullanılan farklı malzemelerin, farklı nem geçirgenlik özelliklerine sahip olmaları nedeni ile taşınan nemin bazı katmanlardan hızlı bir şekilde geçer. Ancak bazı nem geçirgenlik direnci yüksek katmanların önünde birikmektedir. Buna bağlı olarak çevre şartlarına ve tasarım hatalarına bağlı olarak rutubet- nem oluşumu, yani yoğuşma meydana gelebilmektedir. Bu sorunların çözümü için 1sıl ve nem ile ilgili performans ölçütleri doğrultusunda, bir değerlendirme yapılarak, en uygun olanın seçilmesi, tasarım sürecinin önemli bir aşamasını oluşturmaktadır [2]. Dünya genelinde enerji tüketiminin, son 25 yilda kişi başına $\% 5$ artmış olmasına rağmen, Türkiye'de bu oran \%100'ün üzerinde olduğu aktarılmaktadır [3]. Isınma ve 1sıtma için harcanan enerji çok fazladır. Çünkü, yalıtım uygulanmamış konutlarda isıtma için harcanan ortalama enerji tüketimi yılda $200 \mathrm{kWh} / \mathrm{m}^{2}$ nin üzerindedir. Bu konutların 1sıtılması için 3,5 milyar dolar finansal kaynak kullanılmıştır. Günümüzde konutların 1sıtılması için gerekli olan enerji maliyetinin 4 milyar dolar'dan fazla olduğu tahmin edilmektedir. Yapılan hesaplamalar neticesinde tüm bina stoğunun mevcut standartlara göre yalıtılması durumunda enerji tasarrufunun parasal olarak yılda 2 milyar dolar'ın üstünde olacağ1 tahmin edilmektedir [4]. Dünyadaki enerji kaynaklarının büyük bir hızla tükendiğini, Türkiye'de harcanan enerjinin yaklaşık \%40'ının binalarda harcandığını tespit etmiştir. Bu enerjinin \%80'i de ısınma amaçlıdır. Türkiye'de tüketilen enerjinin \%65'inden fazlası ithal edilmektedir. Bu yüzden yalıtım malzemeleri yapılarda önemli oranda 1Sı tasarrufuna katkı sağlamaktadır. Tüm yeni binaların pasif ev seviyesinde inşa edilecek ve mevcut binalar düşük enerji bina standardı karşılamak için yenilenmiş olacaktır. Son yıllarda, bina 1s1 koruma alanında ekolojik özellikleri üzerine daha fazla duruluyor. Çevre bilinci artık enerji tasarrufu ile sınırlı değil, aynı zamanda ekolojik yapı içinde minimum enerji girdisi, kaynak tüketimi de kapsamaktadır. Bu çerçevede yalıtım malzemeleri kullanmanız gerektiğini belirtmiştir [5]. Ülkemizde 1999'dan beri önemli boyutta enerji krizi yaşanmaktadır. Yerli kaynaklı enerji üretimimizin tüketimi karşılama oranı ise $\% 30$ olup, 2020'de \%25'e düşeceği belirtilmiştir. 1999 yılında alınan verilerin enerji tüketimi dağılımı, \%37 sanayi, \%32 konut, \%23 ulaşım, $\% 5$ tarım ve $\% 3$ diğer sektörlerinde olmuştur. 1999'da sadece elektrik dış alımına 1,525 milyar dolar ödenmiş ve petrol ile doğalgaz için de yaklaşık 6 milyar dolar giderimiz vardır. $\mathrm{Bu}$ durum enerji tasarrufunun önemini açık bir şekilde göz önüne sermektedir. Konutlardaki enerji kullanımı \%80'i 1sitma amacı ile harcanması ve sanayide lojmanların, sosyal tesislerin, idare binalarının 1sıtılmaları da göz önüne alındığında 1sıtma amaçlı 1S1 yalıtımı daha da önem kazanmaktadır [6]. Son yıllarda organik atıkların yap1 malzemesi olarak değerlendirilmesi yaygınlaşmaktadır. Kahramanmaraş'ta tekstil fabrikaları çok yaygındır ve sürekli gelişmektedir. 
Bu fabrikalarda tekstil üretim sonucu atık ortaya çıkmaktadır. Bu atıklar her fabrika için ciddi depolama ve çevre sorunlarına neden olmaktadır. Ayrıca bu fabrikaların son atık ürünleri değerlendirilememektedir. Homojen olmayan atıklar da çalışmada değerlendirilmiştir. Pamuk atıklarıyla üretilen blokların üstün 1sı yalıtım özelliğine sahip olduğu ifade edilmektedir [7]. Pamuk atıkları, uçucu kül, epoksi reçine ve barit kullanılarak üretilen yalıtım malzemesinin dayanıklılığı ve ekonomikliği araştırılmıştır. Üretilen yalıtım malzemesinin termal iletkenlik, ultrasonik ses, eğilme dayanımı ve radyoaktif geçirgenlik deneyleri yapılmıştır. Pamuk atıkları ve uçucu külün yalıtım malzemesinin mühendislik özellikleri üzerinde olumlu etkisi olduğu vurgulanmıştır. Pamuk atıkları, uçucu kül ve epoksi reçine ile üretilen hafif yapı malzemeleri daha iyi 1sı ve ses yalıtımı olduğunda yalıtım malzemesi olarak kullanılabileceğini belirtilmiştir [8]. Pamuk atıkları ve tekstil külü ile ürettikleri hafif ve yeni yalıtım malzemesinin özellikleri araştırılmıştır. Blok yalıtım malzemesinin basınç dayanımı ve 1sı iletkenliği deneyleri ASTM ve Türk Standartlarına göre uygulanmıştır. Yapılan deneyler sonucunda; üretilen hafif yalıtım malzemesinin iyi yalıtım özellikleri olduğu ve tuğla, duvar ve tavan panelleri yapımında kullanılan hafif kompozit olduğu vurgulanmıştır [4]. Lignoselülozların kullanımının çok eskilere kadar gittiği ve eski Mısır uygarlığında kerpiç üretiminde çamur ile saman karıştırılarak kullanıldığını aktarmıştır. Bu kerpiçlerin 1sı iletim değerlerinin çok düşük olduğu yapılan çalışmalarla görülmüştür [9]. Kompozit malzemelerin yapılarda kullanılmasıyla, yapılardaki yararlı alanlar artırılmakta 1S1, ses ve nem yalıtımı gibi fiziksel nitelikteki sorunlar çözümlenmekte ve dolayısıyla da yapıların bakım, onarım ve işletme maliyetleri azaltılmaktadır [10]. Son yıllarda atıkların yalıtım malzemesinde katk1 olarak kullanımı araştırılmaktadır. Üretilen blok ve panel yalıtım elemanları üzerinde 1s1 iletim katsayısı tayini, ultrasonik ses geçirgenliği tayini, su emme ve birim hacim ağırlık deneyleri yapılmıştır. Üretilen numuneler, XPS ve gaz beton örnekleriyle karşılaştırılmıştır. Araştırma sonuçları atıklardan üretilen ve tamamen yerli ürün olan yalıtım malzemesinin XPS ve gaz betondan daha iyi 1s1 yalıtımı olduğunu göstermiștir. Sonuçlar söz konusu atıklarının yalıtım malzemesi üretiminde kullanılabileceğini ortaya koymuştur [11]. Önceki çalışmalardan da anlaşılacağı üzere artık dünyamızda atıkların değerlendirilmesi büyük önem arz etmektedir. Bu bağlamada çalışmanın amacı, atıkların değerlendirilerek uygun yalıtım malzemesi üretmektir. Çalışma ile çok daha düşük 1S1 iletim katsayısına sahip olan bir yalıtım malzemesinin üretimi amaçlanmıştır.

\section{MATERYAL VE METOT \\ 2.1. Materyaller \\ 2.1.1. Misir}

Mısır, Haziran-Ağustos ayları arasında çiçekler açan, 1-2 metre yüksekliğinde, bir yıllık, tek evcikli bir kültür ve tahıl bitkisidir. Türkiye'de 500 bin hektarlık alanda misır ziraati yapılmakta olup, (1993) istatistiklerine göre 2.000.000 ton üretilmiştir. Karadeniz, Akdeniz ve Marmara bölgeleri ülkemiz mısır ekim alanlarının $\%$ 90,4'üne, misır üretiminin ise 91,7'sine sahiptir (Şekil 1 ve Şekil 2).

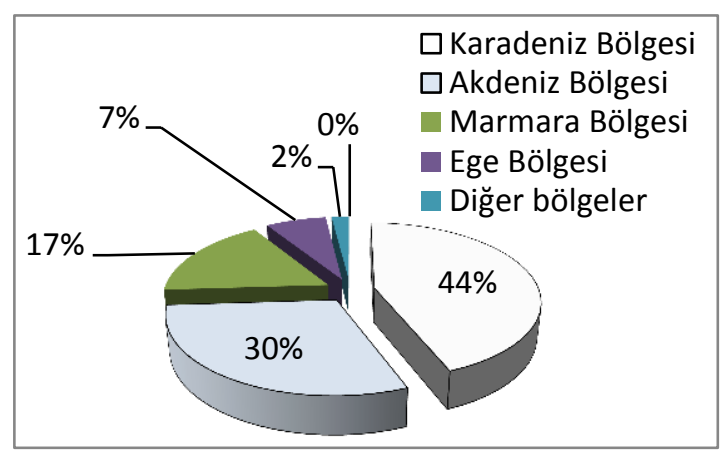

Şekil 1. Türkiye'de mısır ekim alanlarının coğrafi bölgelere göre dağılımı [12]

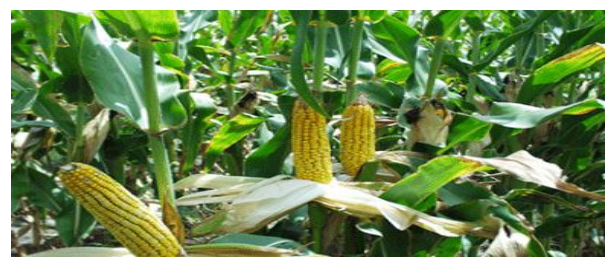

Şekil 2. Misır 


\subsubsection{Epoksi}

Epoksi, viskozitesi artırılmış boya kıvamlı, katkı maddesi sayesinde taş gibi sertleşen bir malzemedir. Epoksi, boyaları ve diğer bazı karışımlarda bağlayıcı olarak kullanılan bir reçine türüdür. Epoksiler iki bileşenlidir ve karıştırılarak kullanılır. Şekil 3'te verildiği gibi bir oksijen atomunun ardışık iki karbon atomuna bağlanarak zincirde üçgen çıkıntı oluşturduğu organik bileşiklerin genel adıdır. Çalışmada bağlayıcı olarak kullanılan epoksi, kimyasal formülü ve ön polimerin hazırlanışının reaksiyon diyagamı Şekil 3 ve Şekil 4'te verilmiştir.
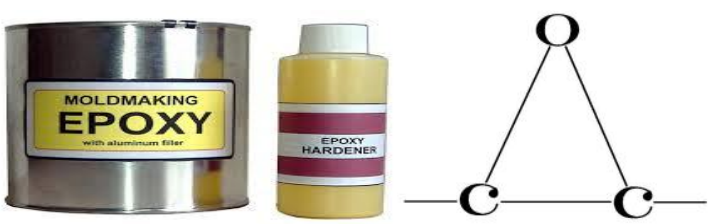

Şekil 3. Epoksi ve kimyasal formülü [13]

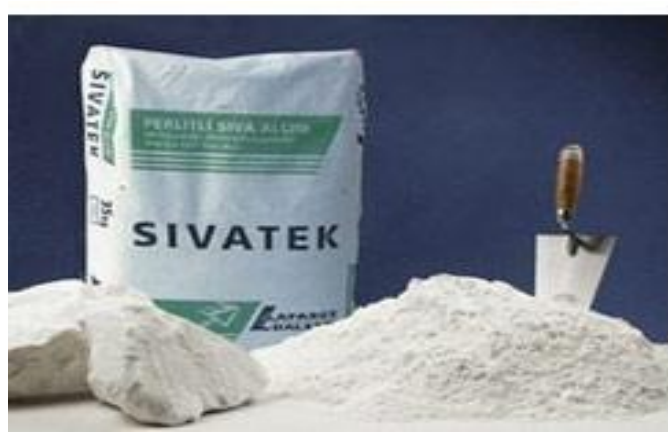

Şekil 5. Alçı

\subsection{4. Çimento}

Çimento, su ile reaksiyona girerek sertleşen bir bağlayıcıdır. Çimentolar TS EN 197-1'de "CEM çimentosu" olarak adlandırılır. Deneysel çalışmalarda, Çimsa Çimento Sanayi A.Ş. Mersin Çimento fabrikasında üretilen CEM I 42,5R Portland Çimento kullanılmıştır.

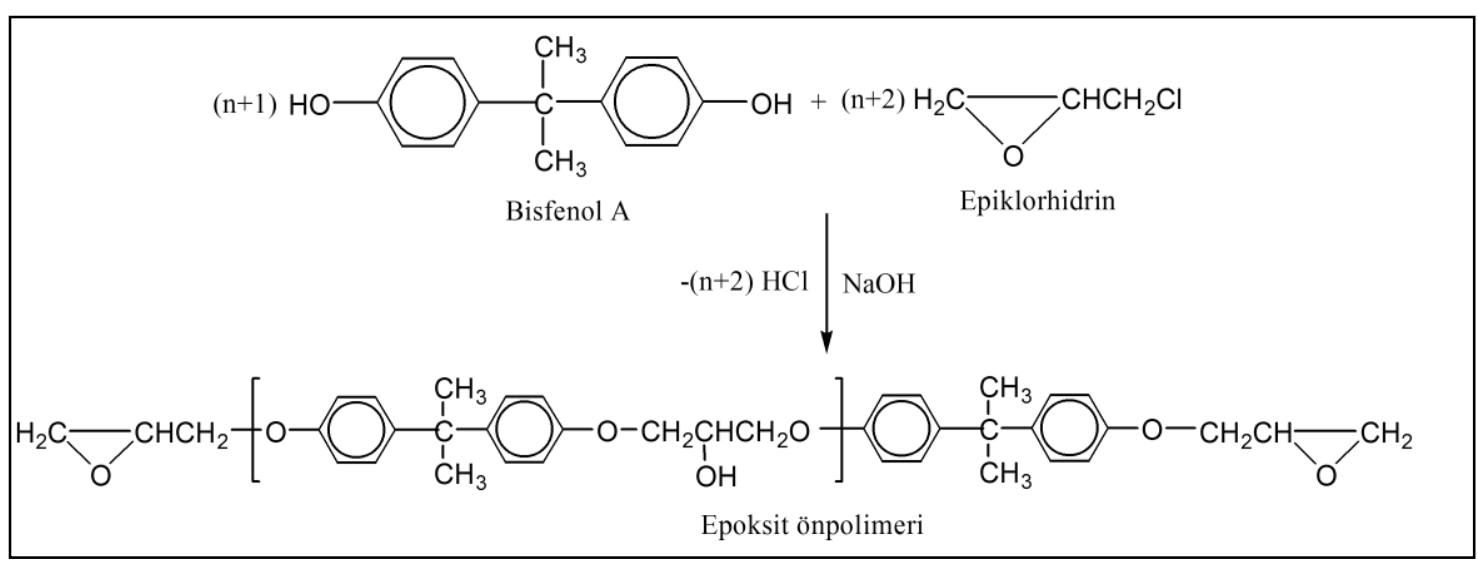

Şekil 4. Epoksi önpolimerin hazırlanışının reaksiyon diyagramı

\subsubsection{Alçı}

Alçıtaşı kimyasal bileşimi kalsiyum sülfat olan bir mineraldir. Bileşiminde iki molekül kristal suyu bulunan türüne jips $\left(\mathrm{CaSO}_{4}+2 \mathrm{H}_{2} \mathrm{O}\right)$ denir. Çalışmada kullanılan alçı Şekil 5 'de verilmiştir.
Portland çimentosunun kimyasal ve fiziksel analizi Mersin Çimsa çimento tesislerinde yapılmıştır.

Kullanılan çimentonun kimyasal ve fiziksel özellikleri Çizelge 1 ve Çizelge 2'de verilmektedir. 
Çizelge 1. Çimentonun kimyasal içeriği

\begin{tabular}{|l|c|}
\hline \multicolumn{1}{|c|}{ Bileşenler } & Yüzde (\%) \\
\hline $\mathrm{SiO}_{2}$ & 18,85 \\
\hline $\mathrm{Al}_{2} \mathrm{O}_{3}$ & 4,80 \\
\hline $\mathrm{Fe}_{2} \mathrm{O}_{3}$ & 2,40 \\
\hline $\mathrm{CaO}$ & 62,80 \\
\hline $\mathrm{MgO}$ & 2,5 \\
\hline $\mathrm{Na}_{2} \mathrm{O}+\mathrm{K}_{2} \mathrm{O}$ & 1,14 \\
\hline $\mathrm{SO}_{3}$ & 3,69 \\
\hline $\mathrm{Serbest}_{\mathrm{CAO}}$ & 0,90 \\
\hline Kizdirma Kayb1 & 3,5 \\
\hline
\end{tabular}
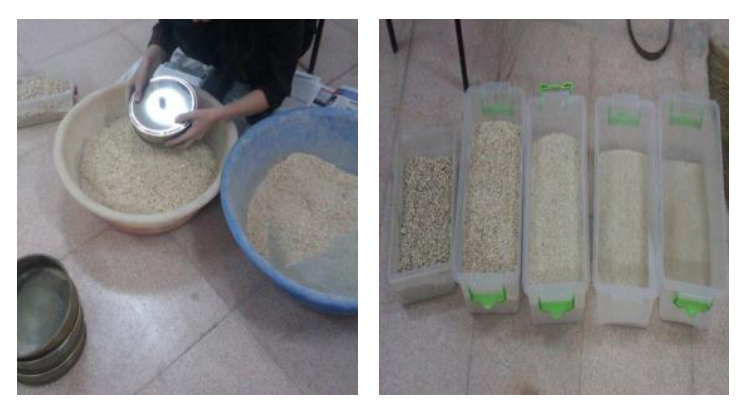

Şekil 6. Mısır koçanı elek analizi

\subsubsection{Yalıtım Malzemesinin Üretilmesi}

Çalışmada mısır koçanı toz haline getirildikten sonra bağlayıcı olarak hem epoksi hemde alçı ve çimento kullanılarak yalıtım malzemesi üretilmiştir.

\begin{tabular}{|c|c|c|c|}
\hline $\begin{array}{c}\text { Özgül } \\
\text { Ağırlık } \\
\left(\mathrm{g} / \mathrm{cm}^{3}\right)\end{array}$ & $\begin{array}{c}\text { Özgül } \\
\text { Yüzey } \\
\left(\mathrm{cm}^{2} / \mathrm{g}\right)\end{array}$ & $\begin{array}{c}200 \mu \text { Elek } \\
\text { Üzerinde } \\
\text { Alan }(\%)\end{array}$ & $\begin{array}{c}90 \mu \text { Elek } \\
\text { Üzerinde } \\
\text { Kalan }(\%)\end{array}$ \\
\hline 3,12 & 3250 & 0 & 2,5 \\
\hline
\end{tabular}

\subsection{Metod}

\subsubsection{Hammaddenin Hazırlanması}

Çalışmada kullanılan mısır koçanı Çukurova Bölgesindeki tarım arazilerinden elde edilmiştir. Elde edilen ürünler ilk aşama olarak etüvde kurutulmuştur. Laboratuvar tipi öğütücü ile istenilen boyutlara getirilmiştir. Mısır koçanın elek analizi Çizelge 3'de verilmiştir (Şekil 6).

Çizelge 3. Mısır koçanı elek analizi

\begin{tabular}{|c|c|}
\hline $\begin{array}{c}\text { Kare göz açıklığı } \\
(\mathbf{m m})\end{array}$ & $\begin{array}{c}\text { Kümülatif elekte geçen } \\
(\mathbf{\%})\end{array}$ \\
\hline 8 & 100 \\
\hline 4 & 78 \\
\hline 2 & 36 \\
\hline 1 & 15 \\
\hline 0,5 & 6 \\
\hline 0,25 & 0 \\
\hline
\end{tabular}

\subsubsection{Bağlayıcı Olarak Epoksi İle Üretilen Yalıtım Levhaları}

Öğütücü ile öğütülen mısır koçanları 0-4 mm boyuta getirilmiştir. Bununla birlikte bağlayıcı olarak epoksi farklı oranlarda kullanılmıştır. Bu numuneler farklı büyüklükte basınç uygulanarak üretilmiştir. Yalıtım malzemesinin karışım oranları Çizelge 4 'de verilmiştir. 10x10x2 cm boyutlarında levhaların üretim aşamaları Şekil 7’de verilmiştir.

Çizelge 4. Karışım oranları

\begin{tabular}{|c|c|c|c|}
\hline \multicolumn{4}{|c|}{ Bileşenler (g) } \\
\hline $\begin{array}{c}\text { N. } \\
\text { Issmi }\end{array}$ & Epoksi & $\begin{array}{c}\text { Mısır } \\
\text { Koçanı }\end{array}$ & $\begin{array}{c}\text { Uygulanan } \\
\text { Basınç(kgf/.cm }\end{array}$ \\
\hline M1 & 30 & 60 & 0,27 \\
\hline M2 & 30 & 60 & 0,22 \\
\hline M3 & 30 & 60 & 0,17 \\
\hline M4 & 30 & 60 & 0,12 \\
\hline M5 & 30 & 60 & 0,07 \\
\hline M6 & 45 & 60 & 0,27 \\
\hline M7 & 45 & 60 & 0,22 \\
\hline M8 & 45 & 60 & 0,17 \\
\hline M9 & 45 & 60 & 0,12 \\
\hline M10 & 45 & 60 & 0,07 \\
\hline
\end{tabular}



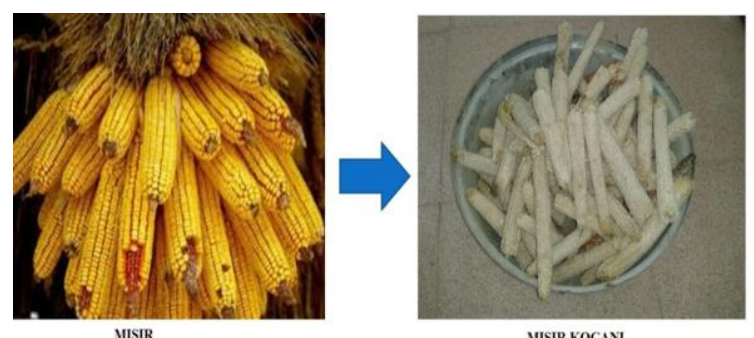

MISIR
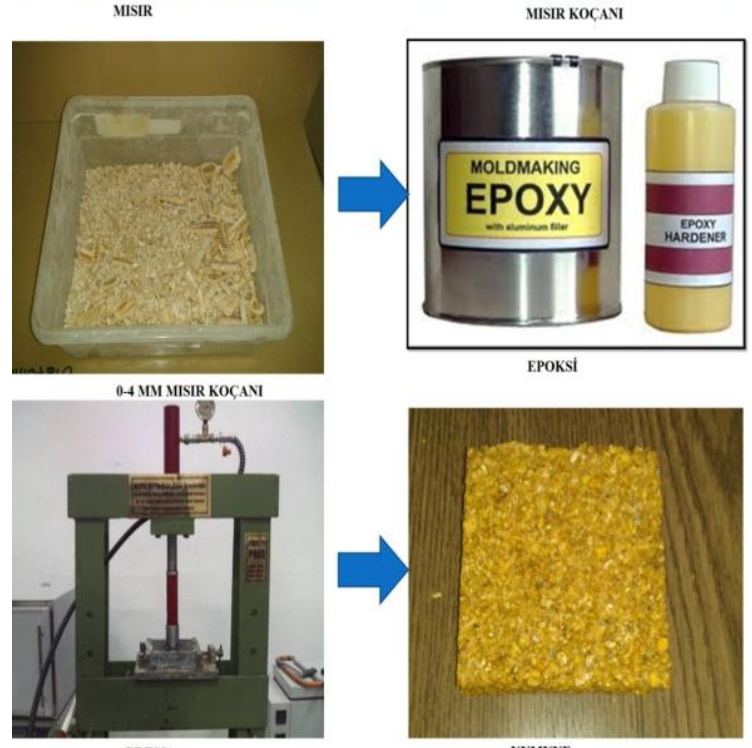

PRESS

Şekil 7. Üretim şeması

\subsubsection{Bağlayıcı Olarak Alçı ve Çimento ile Üretilen Yalıtım Malzemeleri}

Öğütülmüş mısır koçanı, çimento, alçı, $\mathrm{NaOH}$ ve Alimünyum tozu kullanılarak üretilmiştir. Yalıtım malzemesi üretiminde kullanılan hammaddeler Çizelge 5'de ve üretim şeması Şekil 8'de verilmiştir. $10 \times 10 \times 2 \mathrm{~cm}$ boyutlarında üretilen numuneler de Şekil 9'da gösterilmiştir.

Çalıșmanın bu bölümünde Alüminyum tozu ve $\mathrm{NaOH}$ numune içerisinde kullanılarak tepkime oluşturmaktadır. Amaç; tepkimede ortaya çıkan gaz kabarcıklarını numune içinde koruyup boşluk oluşturabilmektir. Böylelikle numunenin 1s1 yalıtım ve ses yalıtım özellikleri iyileştirilmesi hedeflenmektedir. Kimyasal tepkime ekzotermiktir ve su ile birleştirildiğinde tepkime oluşmaktadır.
Çizelge 5. Karışım oranları

\begin{tabular}{|c|c|c|c|c|c|c|}
\hline \multicolumn{7}{|c|}{ Bileşenler (g) } \\
\hline 范 & 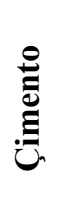 & $\frac{\bar{e}}{\pi}$ & 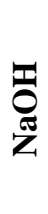 & 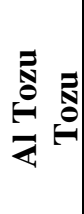 & $\overline{\tilde{S}}$ & 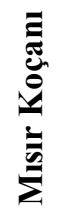 \\
\hline M11 & 250 & 100 & 17 & 8 & 300 & 200 \\
\hline M12 & 200 & 150 & 17 & 8 & 300 & 200 \\
\hline M13 & 150 & 200 & 17 & 8 & 300 & 200 \\
\hline M14 & 100 & 250 & 17 & 8 & 300 & 200 \\
\hline M15 & 50 & 300 & 17 & 8 & 300 & 200 \\
\hline M16 & 250 & 100 & 20 & 10 & 300 & 200 \\
\hline M17 & 200 & 150 & 20 & 10 & 300 & 200 \\
\hline M18 & 150 & 200 & 20 & 10 & 300 & 200 \\
\hline M19 & 100 & 250 & 20 & 10 & 300 & 200 \\
\hline M20 & 50 & 300 & 20 & 10 & 300 & 200 \\
\hline
\end{tabular}

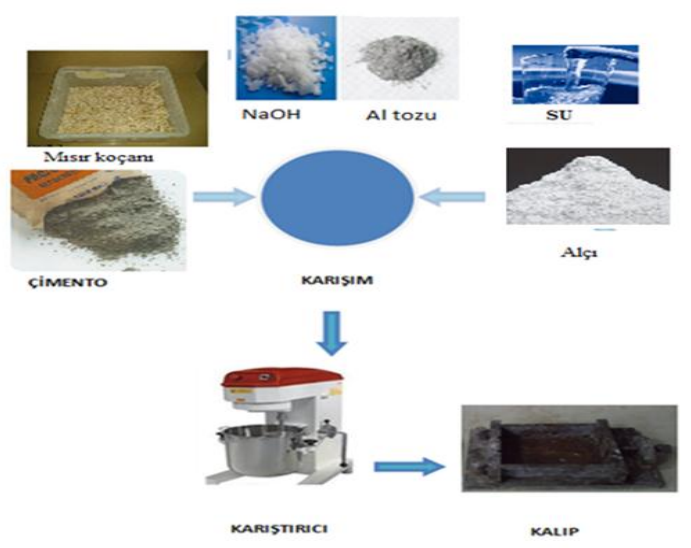

Şekil 8. Yalıtım malzemesi üretim aşamaları 


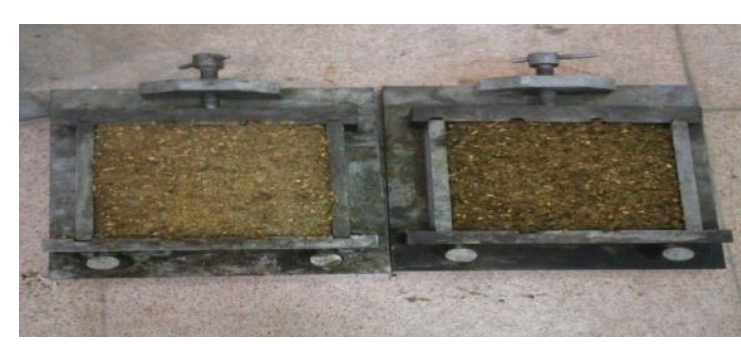

Şekil 9. Üretilen numuneler

\section{DENEYSEL ÇALIŞMALAR}

\subsection{Isı İletim Katsayısı Tayini}

Üretilen kompozit yalıtım malzemesinin 1s1 iletim katsayıs1 KEM marka QTM-500 model termal iletkenlik ölçüm cihazı ile ölçülmüştür. Termal iletkenlik tayini deneyi ASTM C 1113-90 'a göre yapılmıştır (Şekil 10).

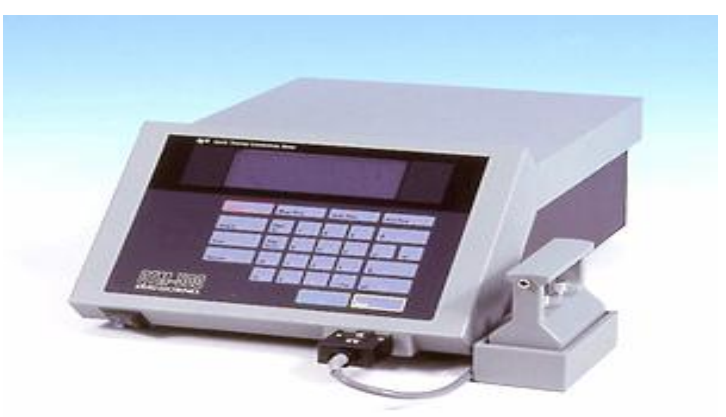

Şekil 10. Termal iletkenlik ölçüm cihazı

\subsection{Ultrasonik Ses Geçirgenliği}

Ses üstü dalganın hızı ile malzemelerin yoğunluğu arasında belirli bir ilişki bulunmaktadır. Malzeme, içerisindeki boşluk miktarı arttıkça, ses üstü dalganın hızı daha az olmaktadır. Malzeme bloğun bir yüzeyinden içeriye gönderilen ses üstü dalganın, bloktaki diğer bir yüzeye ne kadar zamanda geçtiği ölçüldükten sonra, dalga hızı aşağıdaki (1) ifadesi ile hesaplanmaktadır:

$\mathrm{V}=(\mathrm{S} / \mathrm{t}) \times 106$
Burada; $\mathrm{V}=\mathrm{P}$ dalga hızı (kilometre/saniye) $\mathrm{S}=$ Malzemede bloğun ses üstü dalga gönderilen yüzeyi ile dalganın alındığı yüzeyi arasındaki mesafe (kilometre), $\mathrm{t}=\mathrm{P}$ dalganın gönderilmiş olduğu malzeme yüzeyinden, alındığı yüzeye kadar geçen zamandır (mikrosaniye).

Ultrasonik ses geçişi deneyi bütün numuneler üzerinde yapılmış ve ses geçiş hızı bulunmuştur (Şekil 11).

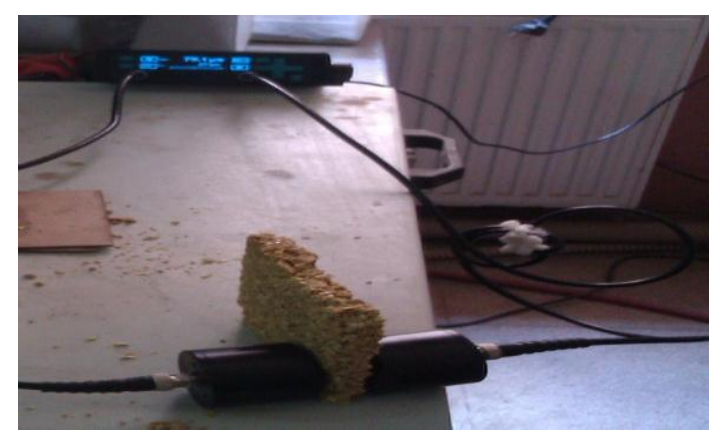

Şekil 11. Yalıtım numunesine ultrasonik ses deneyinin uygulanması

\subsection{Birim Hacim Ağırlık Tayini}

Plak numunenin kurutulmasi sonucu bulunan ağırlığı, $g_{1}$ diş boyutları ölçülerek hesaplanan hacim (v) kullanılarak birim hacim ağırlı̆̆ 1 , B (2) ifadesi ile hesaplanmıştır.

$\mathrm{B}=\frac{\mathrm{g}_{1}}{\mathrm{~V}}$

\subsection{Su Emme Miktarının Bulunması}

Su emme miktarının bulunabilmesi için kurutulan numune tartılıp ağırlık, $g_{1}$ saptanmış ve su içine bırakılmıştır. 24 saat suda bekledikten sonra çıkarılıp ağırlığı, $g_{2}$ kaydedilmiştir.

Sonuçta su emme yüzdesi, w (3) ifadesi ile hesaplanmıştır.

$\mathrm{W}=\frac{\mathrm{g}_{2}-\mathrm{g}_{1}}{\mathrm{~g}_{1}} \times 100$ 


\section{BULGULAR VE TARTIŞMA}

\section{1. Bağlayıcı Olarak Epoksi ile Üretilen Yalıtım Malzemesi Deney Sonuçları}

\subsubsection{Isı İletkenlik Katsayıları}

Mısır koçanı ile üretilen yalıtım malzemesinin 1S1 iletim katsayıları Şekil 12'de verilmiştir.

Numunelere uygulanan basınç azaldığında 1S1 iletim katsayısı değeri de düşmüştür. $\mathrm{Bu}$ örneklerde mısır koçanı ve epoksi miktarları sabit tutulmuştur. Basıncın etkisi $0,27 \mathrm{kgf} / \mathrm{cm}^{2}$ uygulanan M1örneğinin 1s1 iletkenlik katsayıs1 $0,07 \mathrm{kgf} / \mathrm{cm}^{2}$ basınç uygulanan M5 örneği 1S1 iletim katsayısından büyüktür. $\mathrm{Bu}$ durumda optimum basınç miktarı belirlenmesi önem kazanmaktadır. Diğer M7-M10 gubu örneklerde de uygulanan basınç azaltılmış olsa da bu örneklerde kullanılan epoksi miktarı arttığından 1S1 iletim katsayıları da artmıştır.

\subsubsection{Su Emme ve Birim Hacim Ă̆ırlık Değerleri}

Üretilen yalıtım numunelerinin su emme ve birim hacim ağırlı̆̆ı değerleri Şekil 13 ve Şekil 14'de verilmiştir.

Uygulanan basınç miktarı azaldıkça (M2-M5) gubu örneklerin su emme oranları da artmıştır. Burada ilginç olan (M6-M10) gubu örneklerin su emme değerleridir. Zira bu örneklerde en düşük su emme oranına sahip olan numune M10 örneğidir. $\mathrm{Bu}$ örneğe uygulanan basınç en küçüktür.

(M1-M5) gubu örneklerde uygulanan basınç birim hacim ağırlığı değerlerini de arttırmıştır. Bu durum malzemenin doluluk oranı ile açıklanabilir. (M6-M10) gubu örneklerin birim hacim ağırlıkları arasında bir ilişki kurulamamıştır. Bunun nedeni bu örnekler de sabit değişken bulunmaktadır. Yani hem uygulanan basınçlar hem de epoksi miktarı değiştirilmiştir.

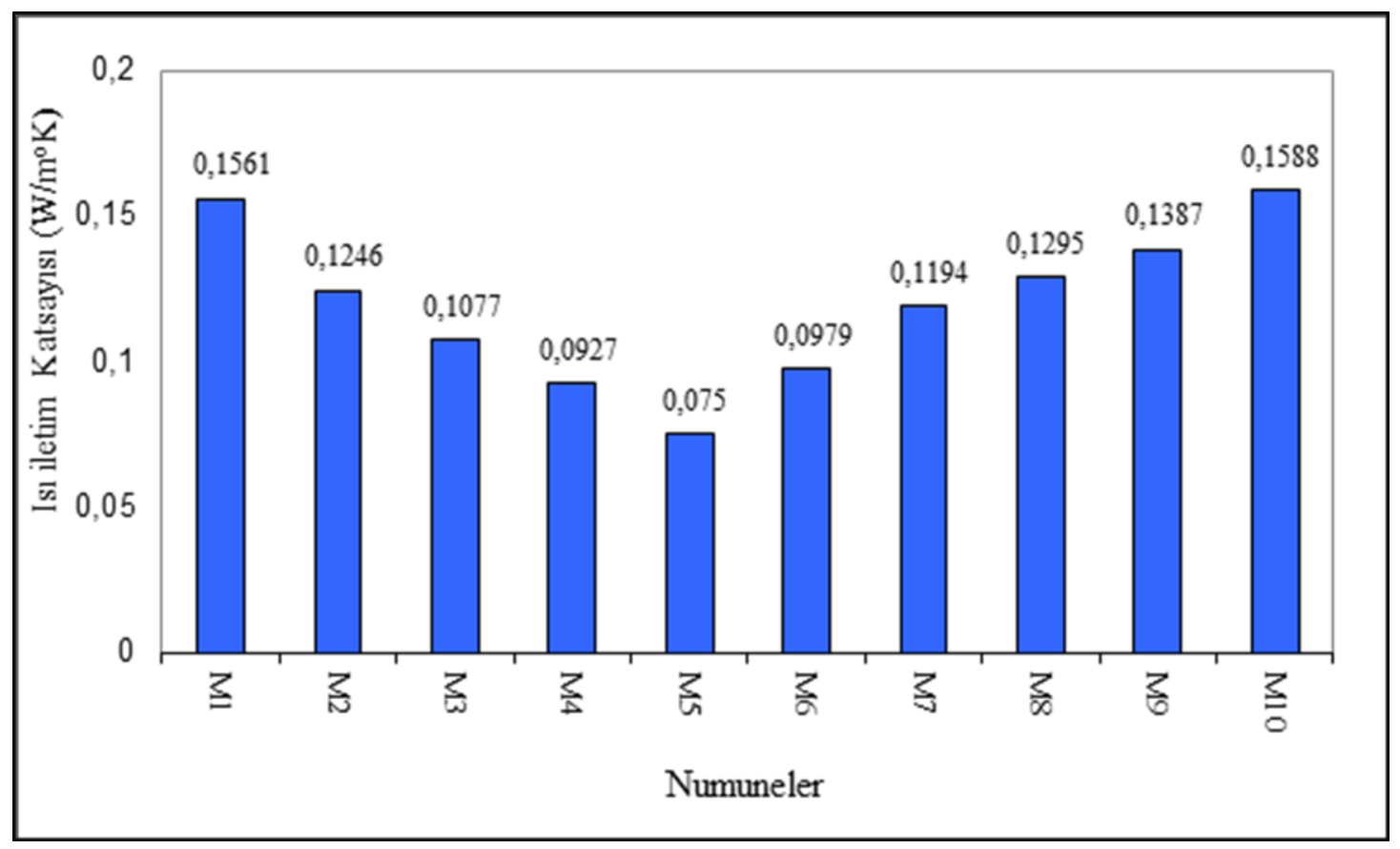

Şekil 12. Mısır koçanı katkılı yalıtım malzemesinin 1sı iletim katsayısı 


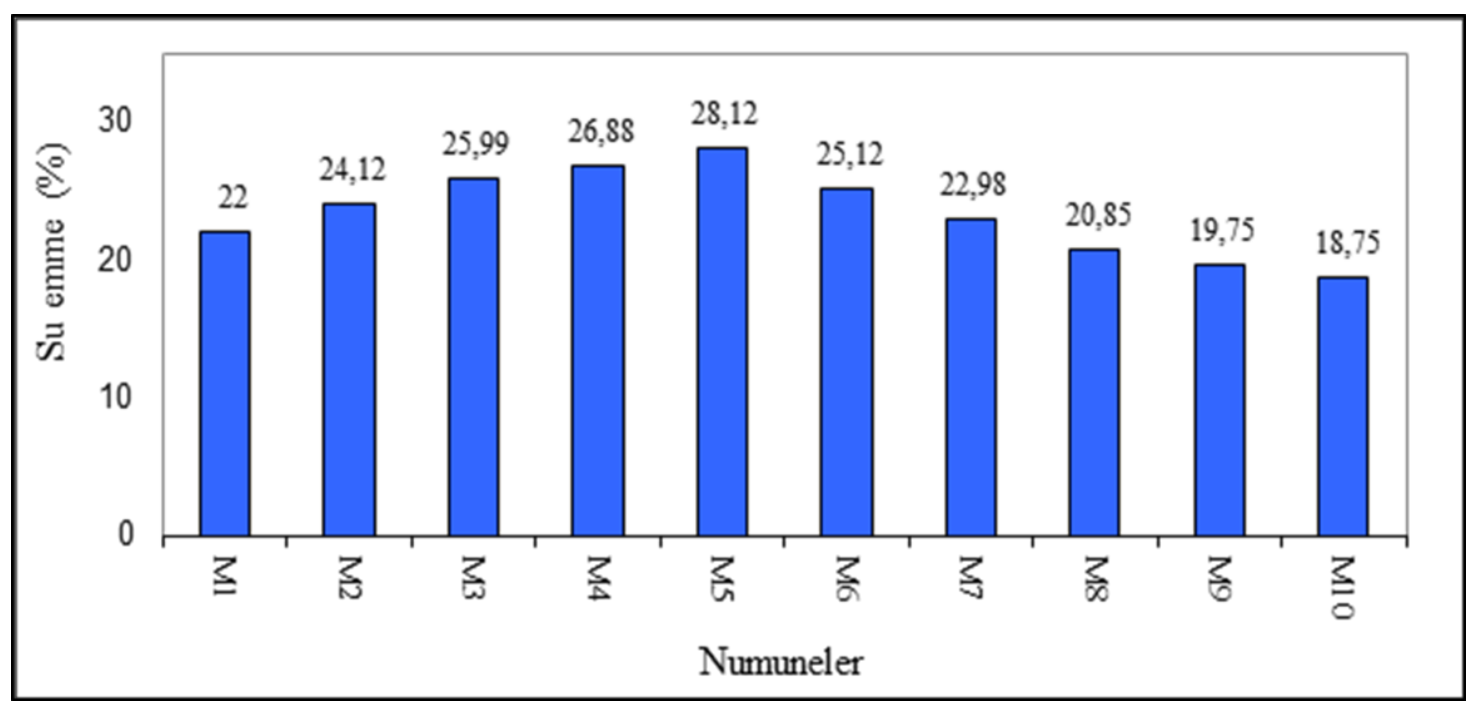

Şekil 13. Mısır koçanı katkılı yalıtım malzemesinin su emme değerleri

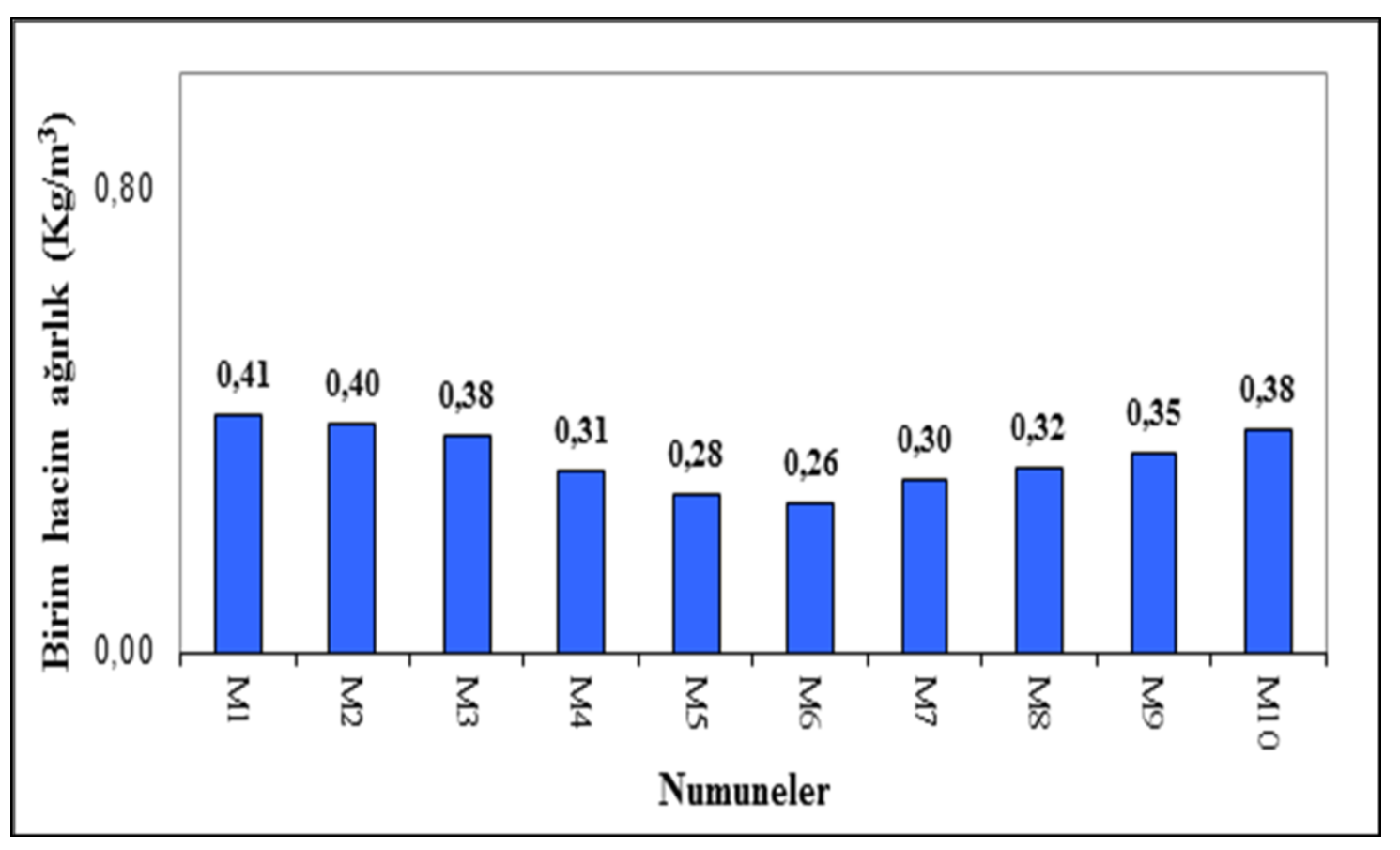

Şekil 14. Mısır koçanı katkılı yalıtım malzemesinin birim hacim ağırlığı değerleri 


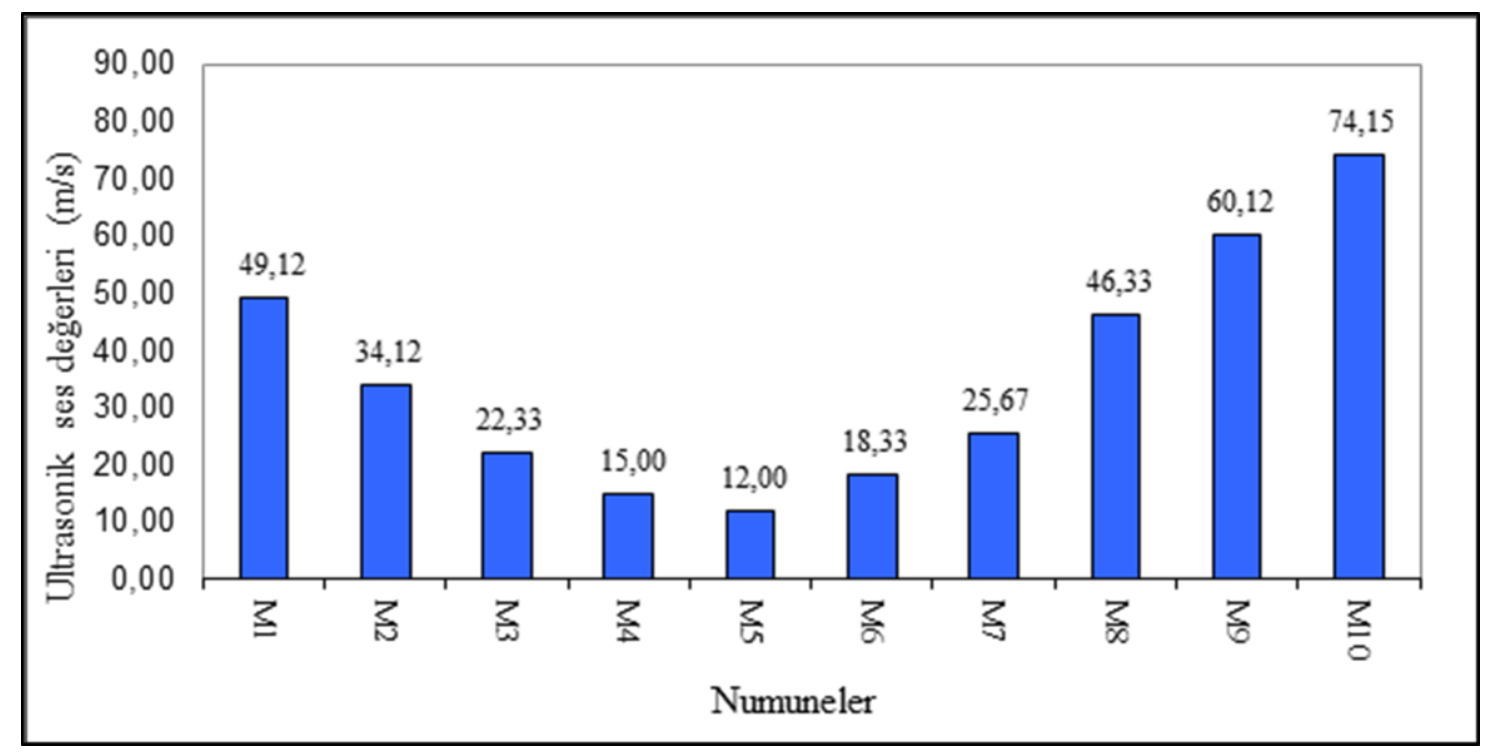

Şekil 15. Mısır koçanı katkılı yalıtım malzemesinin ultrasonik ses değerleri

\subsubsection{Ultrasonik Ses Geçirgenliği}

Mısır Koçanı ile üretilen yalıtım malzemesinin Ultrasonik Ses geçirgenlik değerleri Şekil 15'de verilmiştir.

Örneklere uygulanan basınç azaldıkça boşluklu bir yap1 elde edildiğinden, bu örneklerin sesleri sönümlediği görülmüştür. Yani (M1-M5) gubu örneklerde örneğin M1'in ultrasonik ses geçirgenlik değeri M5'in değerinden \%327 fazladır. (M6-M10) grubu örneklerde ise uygulanan basınç azalmasına rağmen ultrasonik ses geçirgenliği artmıştır. Bunun nedeni epoksi miktarı ile açıklanabilir.

\section{2. Bağlayıcı Olarak Alçı ile Üretilen Yalıtım Malzemesi Deney Sonuçları}

\subsubsection{Isı İletkenlik Katsayıları}

Mısır koçanı ile üretilen yalıtım malzemesinin 1sı iletim katsayısı deneyi yapılmıştır. Bulunan değer Şekil 16'da verilmiştir.
Çimento miktarı azaltılıp, alçı miktarı arttırıldığında 1Sı iletim katsayısı azaltılmıştır (M11-M15). Diğer yandan çimento miktarı azaltılıp, alçı miktarı arttırılmasıyla birlikte $\mathrm{NaOH}$ ve Alüminyum tozu miktarı arttırıldığında 1S1 iletim katsayısı da azaltılmıştır.

\subsubsection{Su Emme ve Birim Hacim Ăğırlık Tayini}

Üretilen yalıtım numuneleri için su emme ve birim hacim ağırlığı değerleri bulunmuştur. Bulunan değerler Şekil 17'de ve üretilen yalıtım levhaları Şekil 18'de verilmiştir. Şekil 17'ye göre çimento miktarı azaldıkça su emme miktarı artmıştır. $\mathrm{Bu}$ durum çimentonun ve alçının yapısı ile açıklanabilir. $\mathrm{NaOH}$ ve Alüminyum miktarı arttıkça su emme miktarı da azda olsa artmaktadır. $\mathrm{Bu}$ durum söz konusu bileşenlerin malzemeyi daha geçirgen hale getirmesi ile açıklanabilir. Çimento miktarı azaltılıp, alçı miktarı arttırıldığında birim hacim ağırlıkları da azalmaktadır. $\mathrm{NaOH}$ ve Alüminyum miktarı azalmasının örneklerinin birim hacim ağırlıkları azda olsa azalmaktadır. 




Şekil 16. Mısır koçanı katkılı yalıtım malzemesinin 1sı iletim katsayısı

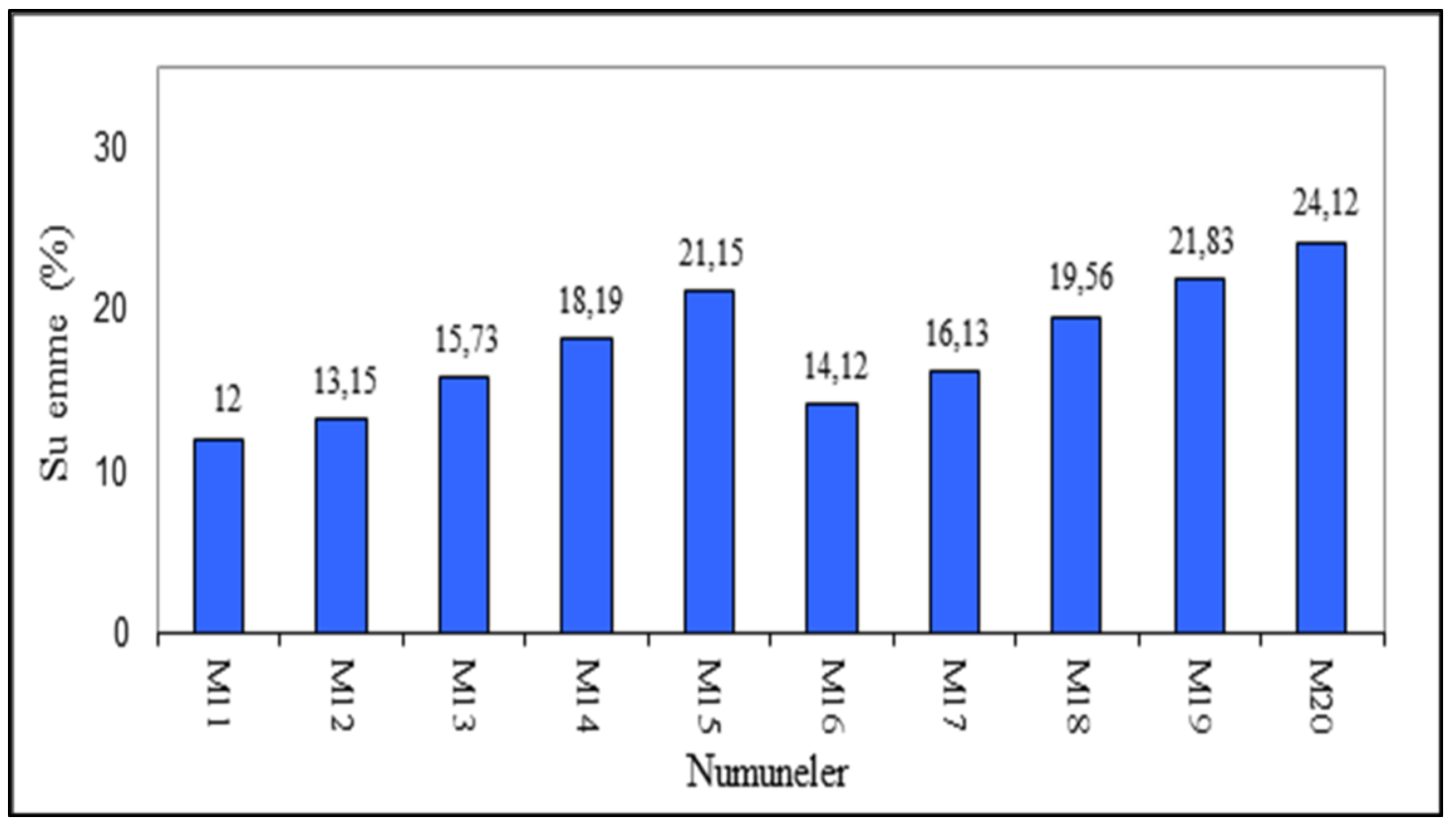

Şekil 17. Mısır koçanı katkılı yalıtım malzemesinin su emme değerleri 


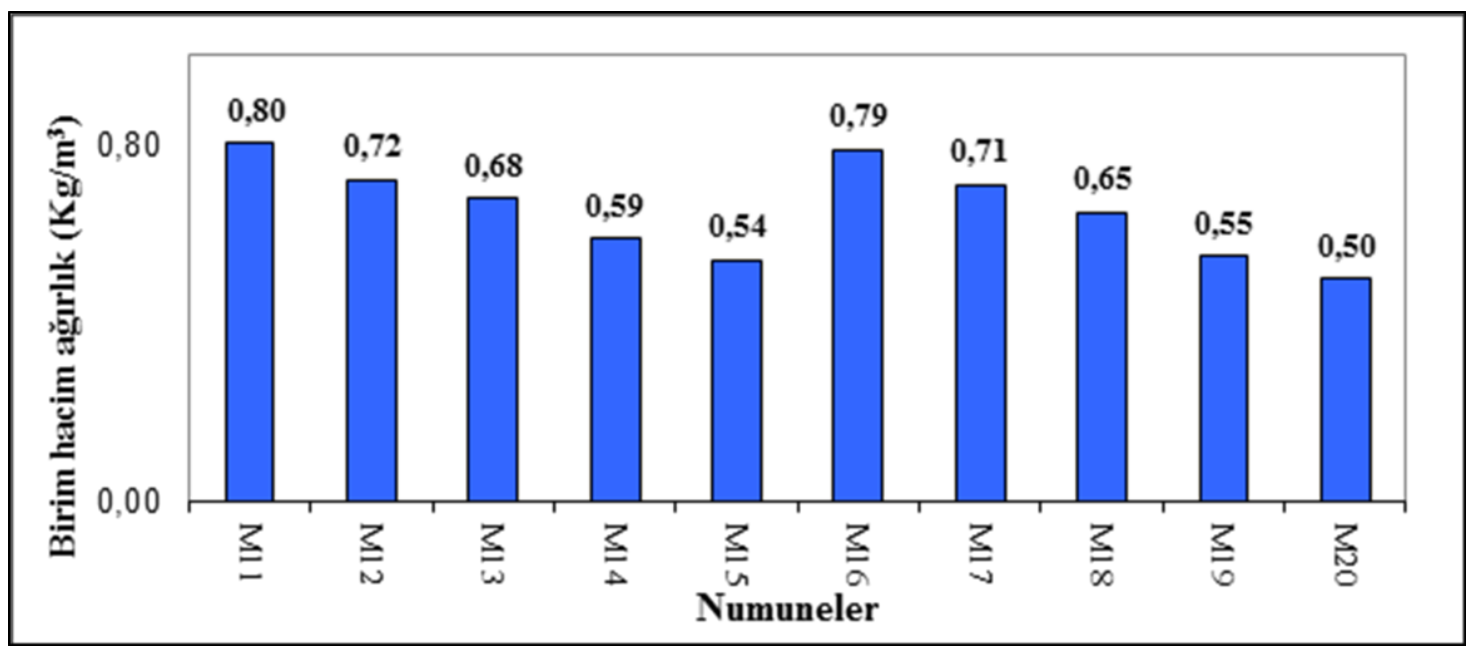

Şekil 18. Mısır koçanı katkılı yalıtım malzemesinin birim hacim ağırlığı değerleri

\subsubsection{Ultrasonik Ses Geçirgenlik Değerleri}

Mısır Koçanı ile üretilen yalıtım malzemesinin Ultrasonik Ses geçirgenlik değerleri Şekil 19'da verilmiştir.

Örneklerdeki çimento miktarı azaltılıp alçı miktarı arttırıldığında ultrasonik ses geçirgenliği de azalmaktadır. Buda daha hafif ve geçirgen bir malzeme yapısı ile açıklanabilir. Çimento ve alçı miktarları sabit tutulduğunda $\mathrm{NaOH}$ ve Alüminyum miktarı arttırıldığında ultrasonik ses geçirgenliği azalmaktadır. $\mathrm{Bu}$ durum yine malzemenin içyapısı ile açıklanabilir.

\section{SONUÇLAR}

Çalışmadan elde edilen sonuçlar aşağıda verilmiştir.

1. Epoksi katkılı numunede $1 \mathrm{~s} 1$ iletkenlik katsayısında en yüksek değere sahip numune $60 \mathrm{~g}$ misır koçanı, 45 g epoksi(uygulanan basınç 0,07 ), en düşük değere sahip numune $60 \mathrm{~g}$ misır koçanı, 30 g epoksi (uygulanan basınç 0,07) kullanılmıştır. Bunun nedeni kullanılan malzemenin epoksinin ve basıncının azalması, malzemelerin boşluk yapısının artması ve yalıtım değerini düşmesi ile açıklanabilir.
2. Su emme deneyinde en yüksek değere sahip numune $30 \mathrm{~g}$ epoksi ve $60 \mathrm{~g}$ misir koçanı(uygulanan basınç 0,07), en düşük değere sahip numune $60 \mathrm{~g}$ misır koçanı ve $45 \mathrm{~g}$ epoksi (uygulanan basınç 0,07) kullanılmıştır. Yalıtım malzemesi basıncının fazla olması daha sıkı yapıya sahip olması ile açıklanabilir.

3. Birim hacim ağırlık deneyinde en yüksek değere sahip numune $30 \mathrm{~g}$ epoksi ve $60 \mathrm{~g}$ misır koçanı(uygulanan basınç 0,27), en düşük değere sahip numune $45 \mathrm{~g}$ epoksi ve $60 \mathrm{~g}$ misır koçanı (uygulanan basınç 0,27) kullanılmıştır. Yalıtım malzemesi fazla boşluk yapısı olması ile açıklanabilir.

4. Ultrasonik ses geçirimliği en yüksek değere sahip numune $45 \mathrm{~g}$ epoksi ve $60 \mathrm{~g}$ mısır koçanı (uygulanan basinç 0,07 ), en düşük değere sahip numune $30 \mathrm{~g}$ epoksi ve $60 \mathrm{~g}$ misır koçanı (uygulanan basınç 0,07) kullanılmıştır. Yalıtım malzemesi basıncının fazla olması ile daha sıkı yapıya sahip olması ile açıklanabilir.

5. Alçı katkılı malzemede $1 \mathrm{~S} 1$ iletkenlik katsayısında en yüksek değere sahip numune $250 \mathrm{~g}$ çimento, $100 \mathrm{~g}$ alçı, $17 \mathrm{~g} \mathrm{NaOH}, 8 \mathrm{~g} \mathrm{Al}$ tozu, $300 \mathrm{~g}$ su ve $200 \mathrm{~g}$ misır koçanı, en düşük değere sahip numune $50 \mathrm{~g}$ çimento, $300 \mathrm{~g}$ alç1, $20 \mathrm{~g} \mathrm{NaOH}$, 


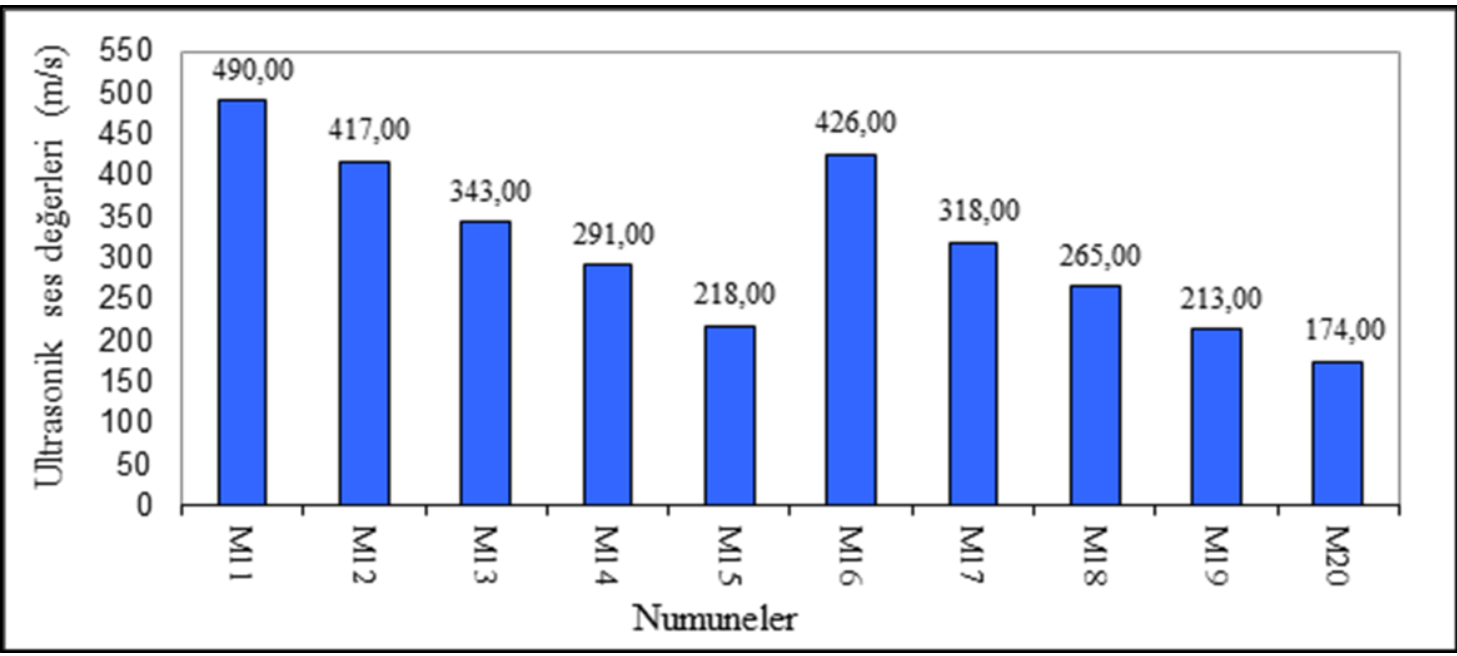

Şekil 19. Mısır koçanı katkılı yalıtım malzemesinin ultrasonik ses değerleri

$10 \mathrm{~g} \mathrm{Al} \mathrm{tozu,} 300 \mathrm{~g}$ su ve $200 \mathrm{~g}$ misır koçanı kullanılmıştır. Kullanılan malzemenin alçı miktarının artması ile açıklanabilir.

6. Su emme deneyinde en yüksek değere sahip numune $50 \mathrm{~g}$ çimento, $300 \mathrm{~g}$ alç1, $20 \mathrm{~g} \mathrm{NaOH}, 10 \mathrm{~g}$ Al tozu, $300 \mathrm{~g}$ su ve $200 \mathrm{~g}$ misır koçanı, en düşük değere sahip numunen $250 \mathrm{~g}$ çimento, $100 \mathrm{~g}$ alçı, $17 \mathrm{~g} \mathrm{NaOH}, 8 \mathrm{~g} \mathrm{Al}$ tozu, $300 \mathrm{~g}$ su ve $200 \mathrm{~g}$ misir koçanı kullanılmıştır.

7. Birim hacim ağırlık deneyinde en yüksek değere sahip numune $250 \mathrm{~g}$ çimento, $100 \mathrm{~g}$ alçı, $17 \mathrm{~g} \mathrm{NaOH}, 8 \mathrm{~g} \mathrm{Al}$ tozu, $300 \mathrm{~g}$ su ve $200 \mathrm{~g}$ misir koçanı, en düşük değere sahip numune $50 \mathrm{~g}$ çimento, $300 \mathrm{~g}$ alçı, $20 \mathrm{~g} \mathrm{NaOH}, 10 \mathrm{~g} \mathrm{Al}$ tozu, $300 \mathrm{~g}$ su ve $200 \mathrm{~g}$ mısır koçanı kullanılmıştır. Yalıtım malzemesi daha fazla çimento miktarı ile daha sıkı yapıya sahip olması ile açıklanabilir.

8. Ultrasonik ses deneyinde en yüksek değere sahip numune $250 \mathrm{~g}$ çimento,100 g alç1, $17 \mathrm{~g} \mathrm{NaOH}, 8 \mathrm{~g}$ Al tozu, $300 \mathrm{~g}$ su ve $200 \mathrm{~g}$ misir koçanı, en düşük değere sahip numune $50 \mathrm{~g}$ çimento, $300 \mathrm{~g}$ alçı, $20 \mathrm{~g} \mathrm{NaOH}, 10 \mathrm{~g} \mathrm{Al}$ tozu, $300 \mathrm{~g}$ su ve $200 \mathrm{~g}$ mısır koçanı kullanılmıştır. Kullanılan malzemenin alçı miktarının artması ile açıklanabilir.
Epoksinin bağlayıcı olarak kullanıldığı söz konusu yalıtım malzemesi standartlarda verilen sinır değerleri sağlamaktadır.

\section{TEŞEKKÜR}

$\mathrm{Bu}$ çalışma, MMF2006D4 nolu proje olarak, Çukurova Üniversitesi Araştırma Projeleri Birimi tarafından desteklenmiş olup, Doktora tezinden alınmıştır.

\section{KAYNAKLAR}

1. Binyıld1z, E., Turan, O., 1999. Binalarda ve Tesisatlarda Is1 Yalıtımı, ODE Teknik Yayınları Yayın 20, İstanbul.

2. Dağsöz, A. K., Bayraktar, K. G., Ünveren, H. H., 2001. Is1 Yalıtımı ve Kalorifer Tesisatı Standartları Üzerine Görüşler, Yapı Malzeme Dergisi, 1 50-54.

3. İzoder, 2005. Türkiye'de Yalıtım Gerçeği, İzoder Yayınları.

4. Aksoy, T.U., 2008. Sandviç ve Gazbeton Duvar Uygulamalarının Ortalama Is1 Geçirgenlik Katsayısı ve Isı Kaybı Üzerindeki Etkisinin İncelenmesi, Erciyes Üniversitesi Fen Bilimleri Enstitüsü Dergisi 24 277- 290. 
5. Tanrıverdi, E., 2004. Isı Yalıtım ve Tasarrufu, Türkiye Mühendislik Haberleri, 427 109-115.

6. Berge, B., 2009. The Ecology of Building Materials. Second ed., 978-1-85617-537-1.

7. Binici, H., Gemci, R., Aksogan, O., Kaplan, H.,, 2010. Insulation Properties of Bricks Made with Cotton and Textile Ash Wastes, International Journal of Materials Research, 101 894-899.

8. Binici, H., Gemci, R., Küçükönder, A., 2012. Investigating the Sound: Insulation, Thermal Conductivity and Radioactivity of Chip Boards Produced with Cottonwaste, Fly Ash and Barite, Construction and Building Materials, 30 826-832.

9. Binici, H., Aksoğan, O., Bodur, M.N, Akça, E., Kapur, S., 2007. Thermal Isolation and Mechanical Properties of Fibrere in Forced Mudbricks as Wall Materials, Construction and Building Materials, 21, 901-906.

10. Uzer, F., 1996. Ahşap Testere Talaşlı Alçı Kompozitler, Yüksek Lisans Tezi, İstanbul Teknik Üniv., Fen Bilimleri Enstitüsü, İstanbul.

11. Binici, H., Sevinç, A.H, Eken, M., 2012. Ayçiçek Sapı ve Tekstil Atıkları ile Yalıtım Malzemesi Üretimi, KSU Mühendislik Bilimleri Dergisi, 15, 1-5.

12. Şahin, G.Ü.S., 2001. Türkiye'de Mısır Ekim Alanlarının Dağılışı ve Mısır Üretimi, Gazi Eğitim Fakültesi Dergisi Cilt 21, Sayı 1, 73-90.

13. Binici, H., Kaplan, H., Temiz, H., Zengin, H., Görür, E.B., 2006. Epoksi ve Epoksinin Yap1 Güçlendirilmesinde Kullanımı, Yapısal Onarım ve Güçlendirme Sempozyumu, 147-153, Denizli. 